\title{
PENGARUH KEDALAMAN TANAM YANG BERBEDA TERHADAP PERTUMBUHAN DAN KUALITAS AGAR RENDEMEN RUMPUT LAUT(Gracilaria gigas)DENGANMETODE LEPAS DASAR
}

\author{
Gani Yusril Fikri', Andi Rahmad Rahim², Farikhah $^{3}$ \\ ${ }^{1}$ Mahasiswa Program Studi Akuakultur, Fakultas Pertanian, Universitas Muhammadiyah Gresik \\ ${ }^{2}$ Dosen Program Studi Akuakultur, Fakultas Pertanian, Universitas Muhammadiyah Gresik \\ ${ }^{3}$ Dosen Program Studi Akuakultur, Fakultas Pertanian, Universitas Muhammadiyah Gresik \\ Email : ganiyusril@yahoo.com ; Phone No. +6281281545056
}

\begin{abstract}
Gresik Regency is faced with the problem of development which is less attention to spatial arrangement where the pond land is threatened by land conversion for settlement, urban development, and industry. As one of the Minapolitan areas in Indonesia, the profile of pond farming in Gresik Regency needs attention. The purpose of this research is to analyze the growth of Gracilaria gigas seaweed in ponds with different depth of cultivation and to analyze the quality in order to rendemen Gracilaria gigas seaweed in ponds with different depth of cultivation, which is cultivated by the off bottom method. The study was conducted in February 2018 with a study duration of 42 days. The test plants used in this study were seaweed of Gracilaria gigas species, which were cultivated by the off bottom method. The experimental design used was complete randomized design (RAL) with 4 different planting depth treatment and 3 replications ie treatment A (depth $20 \mathrm{~cm}), \mathrm{B}($ depth $40 \mathrm{~cm}), \mathrm{C}($ depth $60 \mathrm{~cm})$ and D (depth $0 \mathrm{~cm}$ ).
\end{abstract}

Keywords: Depth of planting, Growth, Quality for the yield of Gracilaria gigas, Off bottom method

\begin{abstract}
ABSTRAK
Kabupaten Gresik dihadapkan pada masalah pembangunan yang kurang memperhatikan penataan ruang di mana lahan tambak terancam alih fungsi lahan untuk permukiman, pengembangan kota, dan industri. Sebagai salah satu kawasan Minapolitan di Indonesia, maka profil budidaya tambak di Kabupaten Gresik perlu mendapat perhatian.Tujuan dari penelitian ini yaitu untuk menganalisispertumbuhan rumput laut Gracilaria gigas di tambak dengan kedalaman tanam yang berbeda dan menganalisis kualitas agar rendemen rumput laut Gracilaria gigas di tambak dengan kedalaman tanam yang berbeda, yang dibudidayakan dengan metode lepas dasar. Penelitian ini dilaksanakan pada bulan Februari 2018 dengan lama penelitian 42 hari. Tanaman uji yang digunakan dalam penelitian ini adalah rumput laut dari jenis Gracilaria gigas, yang dibudidayakan dengan metode lepas dasar. Rancangan percobaan yang digunakan adalah rancangan acak lengkap (RAL) dengan 4 perlakuan kedalaman tanam yang berbeda dan 3 kali ulangan yaitu perlakuan A (kedalaman $20 \mathrm{~cm}$ ), B (kedalaman40 cm), C (kedalaman60 $\mathrm{cm}$ ) dan $\mathrm{D}$ (kedalaman $0 \mathrm{~cm}$ ).
\end{abstract}

Kata kunci : Kedalaman tanam, Pertumbuhan, Kualitas agar rendemen Gracilaria gigas, Metode lepas dasar 


\section{PENDAHULUAN}

Kabupaten Gresik dihadapkan pada masalah pembangunan yang kurang memperhatikan penataan ruang di mana lahan tambak terancam alih fungsi lahan untuk permukiman, pengembangan kota, dan industri. Sebagai salah satu kawasan Minapolitan di Indonesia, maka profil budidaya tambak di Kabupaten Gresik perlu mendapat perhatian. Oleh karena itu, dilakukan penelitian yang bertujuan untuk mengetahui potensi lahan tambak dan profil budidaya tambak di Kabupaten Gresik dalam pemanfaatan budidaya rumput kaut yang kurang di minati dan kurangnya ilmu teknik metode budidaya rumput laut dalam tingkat produktifitas budidaya rumput laut di tambak menurun untuk mendukung program Minapolitan. Teknologi penginderaan jauh dan sistem informasi geografis diaplikasikan dalam penentuan potensi lahan budidaya tambak. Profil budidaya tambak diketahui dari pengamatan di lapangan dan dari berbagai informasi yang ada. Hasil penelitian menunjukkan bahwa luas tambak di Kabupaten Gresik pada tahun 2011 mencapai 30.904,5 ha.

Pengembangan rumput laut Gracilaria gigas belum optimal dilakukan. Berdasarkan data Departemen Kelautan dan Perikanan (DKP) total produksi rumput laut tahun 2007 sebanyak 1,62 juta ton atau naik dibandingkantahun 2006 yaitu 1,37 juta ton. Hanya $15 \%$ dari total produksi rumput laut diolah di dalam negeri, selebihnya diekspor dalam bentuk bahan mentah rumput laut kering (Kompas, 2008). Sementara itu, permintaan rumput laut terus meningkat dari tahun ke tahun.Kebutuhan dunia sekitar 80.000 ton per tahun, digunakan sebagai bahan makanan (Satari, 2001).

Menurut McHugh (2003), pada era awal industri agar di negara Chili, Gracilaria gigas hanya diambil dan dikumpulkan dari alam untuk mendukung suplai Gelidium yang menjadi penghasil utama agar. Meningkatnya kebutuhan bahan baku industri tidak dapat dipenuhi oleh produksi spesies Gelidium. Oleh karena itu, teknik budidaya Gracilaria mulai dikembangkan baik di tambak maupun di laut.Teknik budidaya tersebut yang kemudian tersebar ke berbagai negara seperti Korea, Cina, Namibia, Filipina, Indonesia, dan Vietnam.

Menurut Zatnika (1997), di Indonesia Gracilaria merupakan spesies utama yang dibudidayakan sebagai komoditas penghasil agar. Namun produksi Gracilaria dari hasil budidaya di tambak belum dapat memenuhikebutuhan pasar. Salah satu upaya untuk meningkatkan produksi adalah dengan cara mengembangkan budidaya Gracilaria di laut.

Kunci utama keberhasilan budidaya rumput laut sangat tergantung dari teknologi budidaya yang cocok diterapkan pada kondisi perairan. Menurut Kadi dan Atmadja (1988), metode budidaya rumput laut berdasarkan posisi tanamanterhadap dasar perairan, dibedakan 3 cara yaitu metode dasar, lepas dasar, dan apung. Pada prinsipnya metode dasar dan lepas dasar sama dengan metode apung, perbedaan hanya pada peletakan budidayanya dipengaruhi oleh kedalaman. Lebih lanjut Aslan (2006) menyatakan bahwa teknik penanaman pada metode budidaya dapat dilakukan dengan sistem tali tunggal dan jaring.Pada sistem tali tunggal, bibit diikatkan pada tali nilon yang direntangkan pada rakit.

\section{TINJAUAN PUSTAKA}

Gracilaria $s p$ adalah rumput laut penghasil agar-agar dari kelas Rhodophyceae (ganggang merah), famili Gracilariaceae. Sedangkan agar-agar adalah hydrophylic colloid atau senyawa polysacharida yang diekstraks dari ganggang merah (Rhodophyceae) yang tidak larut dalam air dingin tetapi larut dalam air panas Struktur utama agar-agar adalah Agarobiose yang terdiri dari ikatan $\beta$ (1-4) D-galactose dan $\alpha$ (1-3) 3,6 -anhydro-galactose secara bergantian atau terbentuk dari rangkaian ikatan 1,3 
b-D galaktopiranosa dan ikatan 1,4-3,6 anhidro-a-galaktopiranosa (Zatnika dan Istini, 2009).

Agar-agar menjadi sangat penting karena memiliki fungsi sebagai zat pengental, pengemulsi, penstabil dan pensuspensi yang banyak digunakan dalam berbagai industri seperti industry makanan, minuman, farmasi, biologi dan lain lain. Sebagian besar agaragar digunakan dalam industri makanan dalam bentuk jely, ice cream, makanan kaleng (daging dan ikan) dan roti, permen manisan, pemen selai (Anggadiredja et al., 2006).

Proses fotosintesis rumput laut menghasilkan beberapa zat penting dan mempunyai nilai ekonomis tergantung dari spesiesnya, antara lain floridin starch, mannoglycerate dan floridosida. Lebih spesifik lagi dikenal dengan polisakarida berupa agar-agar dan keraginan. Gracilaria gigas digolongkan pada kelompok agarofit karena dapat menghasilkan agar. Habitat asli dari rumput laut Gracilaria gigas adalah di perairan pantai (Zatnika, 2009).

\section{MATERI DAN METODE}

Penelitian ini menggunakan metode lepas dasar penanaman rumput laut dengan cara mengikat bibit pada seutas tali yang direntangkan dalam air dengan bantuan tiang pantang atau patok, dengan ukuran panjang tali ris $1 \mathrm{~m}$ sebanyak 12 buah tali ris, setiap sudut di beri balok kayu yang ditancapkan sebagai penahan tali ris agar tidak terombang ambing, dengan jarak masing - masing tali ris $30 \mathrm{~cm}$ dengan bobot awal benih 10g.Setiap kedalaman rumput laut di berikan pemberat batu agar tidak terombang ambing oleh arus air.

Sedangkan waring yang digunakan untuk media penelitian ukuran 1x4 meter.Perlakuan yang akan diujikan menggunakan Rancangan Acak Lengkap (RAL) yaitu penggunaan kedalaman tanam $20 \mathrm{~cm}$ (A) dari permukaan air, $40 \mathrm{~cm}$ (B) dari permukaan air, $60 \mathrm{~cm}$ (C) dari permukaan air, dan kontrol (D) $0 \mathrm{~cm}$ dari permukaan air dengan menggunakan ujung thallus yang subur, masing - masing perlakuan mendapat 3 ulangan.

Data penelitian rumput laut Gracilaria gigasyang dikumpulkan meliputi bobot mutlak, laju pertumbuhan harian, kualitas agar dan rendemen.Laju pertumbuhan harian diukur setiap satu minggu sekali hingga akhir penelitian. Laju pertumbuhan ini dihitung dengan menggunakan rumus Specific Growth Rate ( SGR ) Anggadireja et al.(2009) :

$$
S G R=\frac{L n W t-L n W o}{t} \times 100 \%
$$

\section{Keterangan :}

SGR : Laju pertumbuhan harian rata - rata (\%BB/hari )

Wt : Berat rata - rata pada $t_{i}(g)(I=$ minggu $I$, minggu II , ... t $)$

Wo : Berat rata - rata pada $\mathrm{t}_{\mathrm{i}-1}(\mathrm{~g})$

$\mathrm{T} \quad$ : Periode penanaman ( hari )

Pertumbuhan mutlak rumput laut diamati dari awal hingga berakhirnya penelitian Pertumbuhan mutlak diukur dengan menggunakan rumus pertumbuhan mutlak :

$$
G=W t-W o
$$

Keterangan :

G. : Pertumbuhan mutlak rata - rata ( g )

Wt : Berat rata - rata bibit pada akhir penelitian $(\mathrm{g})$

Wo : Berat rata - rata bibit pada awal penelitian $(\mathrm{g})$ 
Rendemen rumput laut kering dapat dihitung dengan menggunakan persamaan (AOAC,2005):

Rendemen $(\%)=\left(\frac{\text { Berat kering }}{\text { Berat basah }}\right) \times 100 \%$

Hasil perhitungan data dianalisis menggunakan bantuan program Microsoft Excel 2007 untuk tabulasi data dan penyajian grafik. Untuk mengetahui pengaruh yang berbeda terhadap pertumbuhan, kualitas agar rendemen rumput laut Gracilaria gigas maka menggunakan analisis sidik ragam Analysis of Variance (ANOVA) yang bertujuan untuk melihat apakah data berpengaruh secara signifikan atau tidak. Dengan menggunakan cara perhitungan dari program aplikasi SPSS 16.0. kemudian dilanjutkan dengan uji Tukey jika berpengaruh secara signifikan dengan taraf kepercayaan $95 \%$.

\section{HASIL DAN PEMBAHASAN}

\section{Kualitas Agar Rendemen Rumput Laut (Gracilaria gigas)}

Gambar 1. menunjukkan kualitas agar rendemen rumput laut G. gigas pada perlakuan A $(20 \mathrm{~cm})$ sejumlah $40,04 \%$, perlakuan B $(40 \mathrm{~cm})$ sejumlah $35,92 \%$, perlakuan C $(60 \mathrm{~cm})$ sejumlah $31,20 \%$ dan perlakuan D $(0 \mathrm{~cm})$ sejumlah $33,36 \%$. Hasil uji ANOVA pada kualitas agar rendemen rumput laut $G$. gigas menunjukkan bahwa perlakuan kedalaman tanam yang berbeda memberikan pengaruh yang signifikan terhadap variabel yang diamati $(\mathrm{p}<0,05)$. Sehingga dilanjutkan untuk uji lanjut Tukey.

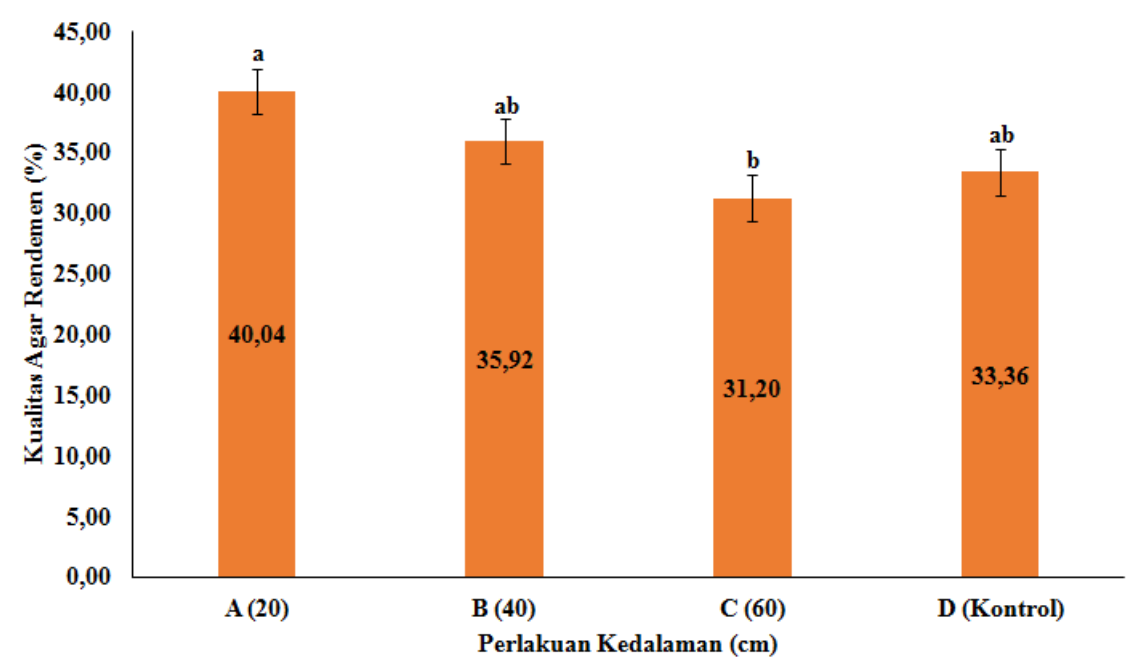

Gambar 1. Grafik Kualitas Agar Rendemen (\%) Rumput Laut G.gigas.

Berdasarkan uji Tukey perlakuan yang menghasilkan nilai tertinggi adalah perlakuan A $(20 \mathrm{~cm})$, di susul dengan perlakuan B $(40 \mathrm{~cm})$ namun tidak berbeda dengan perlakuan D $(0 \mathrm{~cm})$, dan angka terendah adalah perlakuan $C(60 \mathrm{~cm})$. Pada perlakuan D $(0 \mathrm{~cm})$ terdapat hewan kecil yang menempel pada thalus sehinga menghambat fotosintesis rumput laut.Perbedaan perlakuan kedalaman budidaya menyebabkan rumput laut berada pada kedalaman yang berbeda. Semakin dalam perairan maka intensitas cahaya semakin berkurang sehingga proses fotosintesis tidak optimal. Menurut Sujatmiko danWisman (2003) rumput laut yang berada di permukaan relatif lebih banyak mendapatkan cahaya matahari dibandingkan rumput laut yang berada di bagian yang lebih dalam. Widyartini dan Insan (2004) menambahkan intensitas cahaya yang diterima semakin kecil, maka proses fotosintesis terhambat danpertumbuhan tidak optimal. 


\section{Pertumbuhan Rumput Laut (Gracilaria gigas)}

Hasil pengamatan pertumbuhan thalus rumput laut Gracilaria gigas yang ditanam dengan metode lepas dasar pada kedalaman yang berbeda di tambak dukun, Gresik menunjukkan bahwa dengan bertambahnya umur tanam maka pertambahan berat basah semakin meningkat (Gambar 2).

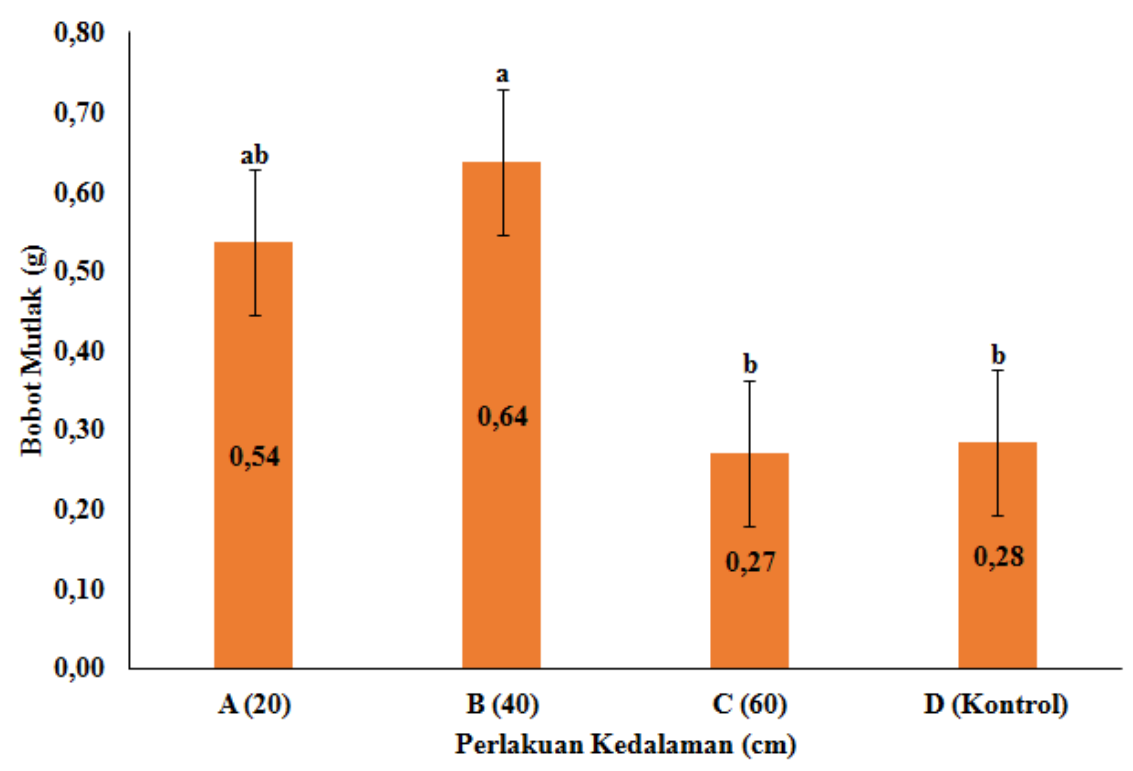

Gambar 2.Grafik bobot mutlak (g) Rumput Laut G. Gigas.

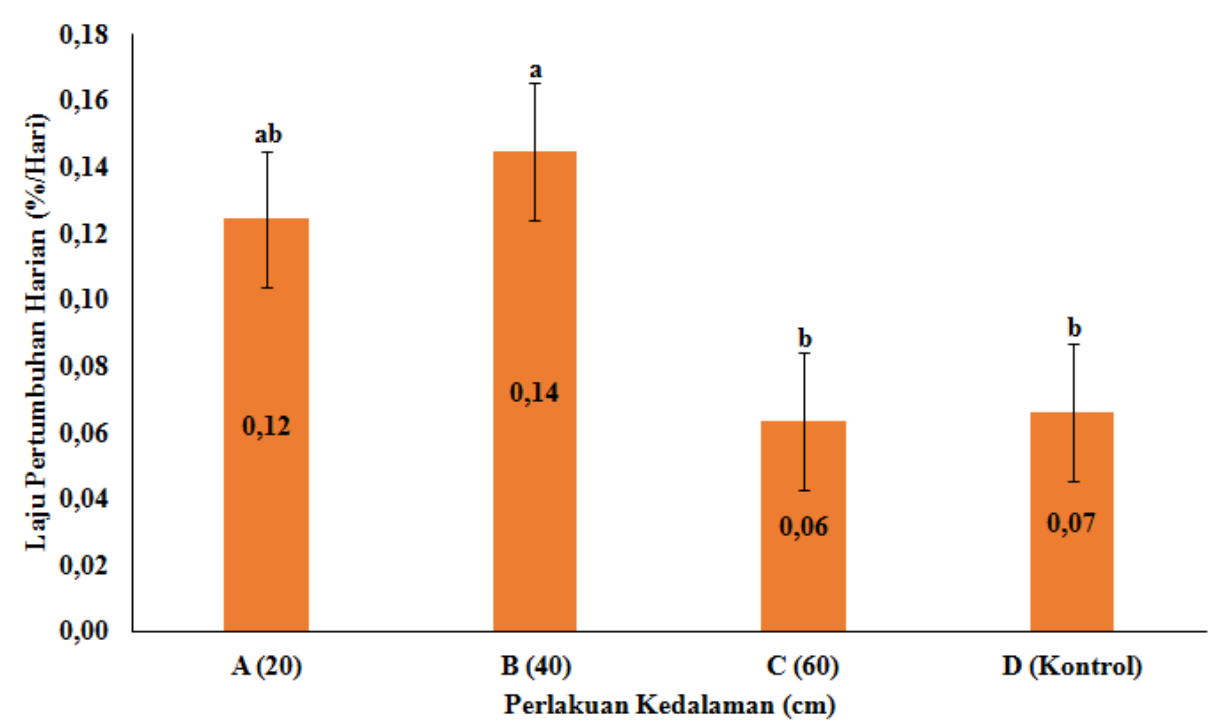

Gambar 3.Grafik Laju Pertumbuhan Harian (\%/Hari) Rumput Laut G. gigas.

Gambar 2. menunjukkan bobot mutlak rumput laut G. gigas pada perlakuan A (20 cm dari permukaan air) sejumlah $0,54 \mathrm{~g}$, perlakuan B $(40 \mathrm{~cm}$ dari permukaan air) sejumlah 0,64 g, perlakuan $\mathrm{C}(60 \mathrm{~cm}$ dari permukaan air) sejumlah $0,27 \mathrm{~g}$ dan perlakuan D $(0 \mathrm{~cm}$ dari permukaan air) sejumlah $0,28 \mathrm{~g}$. Hasil Analysis of Variance (ANOVA) bahwa, kedalaman tanam yang berbeda memberikan pengaruh yang signifikan terhadap bobot mutlak rumput laut $G$. gigas $(\mathrm{P}<0,05)$. Sehingga dilakukan uji lanjut Tukey bahwa, perlakuan B $(40 \mathrm{~cm})$ menghasilkan pertumbuhan tertinggi, di ikuti oleh 
perlakuan A $(20 \mathrm{~cm})$ yang tidak berbeda dengan perlakuan B $(40 \mathrm{~cm})$. perlakuan $\mathrm{C}$ $(60 \mathrm{~cm})$ menghasilkan pertumbuhan terendah dan tidak berbeda dengan perlakuan $\mathrm{D}$ $(0 \mathrm{~cm})$. Tingginya pertumbuhan mutlak pada perlakuan kedalaman tanam $40 \mathrm{~cm}$ dikarenakan pada kedalaman tanam $40 \mathrm{~cm}$ secara nyata mempangaruhi pertumbuhan rumput laut dari kualitas perairan tambak, parameter lingkungan yang sangat erat kaitannya dengan pertumbuhan talus rumput laut adalah suhu, $\mathrm{DO}, \mathrm{PO}_{4}-\mathrm{P}$ dan $\mathrm{NH}_{3}-\mathrm{N}$.

Gambar 3. menunjukkan laju pertumbuhan harian rumput laut Gracilria gigas pada perlakuan A $(20 \mathrm{~cm}$ dari permukaan air) sejumlah $0,12 \% /$ hari, perlakuan B $(40 \mathrm{~cm}$ dari permukaan air) sejumlah $0,14 \% /$ hari, perlakuan $\mathrm{C}(60 \mathrm{~cm}$ dari permukaan air) sejumlah $0,06 \%$ /hari dan perlakuan D (0 cm dari permukaan air) sejumlah $0,07 \%$ /hari. Hasil Analysis of Variance (ANOVA) bahwa, kedalaman tanam yang berbeda memberikan pengaruh yang signifikan terhadap laju pertumbuhan harian rumput laut gracilaria gigas $(\mathrm{P}<0,05)$. Sehingga dilakukan uji lanjut Tukey menghasilkan kesimpulan bahwa perlakuan kedalaman tanam $40 \mathrm{~cm}$ (Perlakuan B) adalah yang terbaik namun tidak berbeda dengan perlakuan Kedalaman tanam $20 \mathrm{~cm}$ (Perlakuan A) $(\mathrm{P}<0,05)$. Sedangkan perlakuan kedalaman tanam $60 \mathrm{~cm}$ (Perlakuan $\mathrm{C}$ ) menghasilkan pertumbuhan terendah namun tidak berbeda dengan perlakuan kedalaman tanam $0 \mathrm{~cm}$ (Perlakuan D). Hal ini sesuai dengan pendapat Mubarak et al., (1982) bahwa syarat tumbuhnya rumput laut Gracilaria yaitu pada kedalaman sekitar $30 \mathrm{~cm}$ selama bulanbulan berawan dan $60 \mathrm{~cm}$ selama bulan-bulan tak berawan. Sedangkan menurut Anam (2007) kedalaman pada budidaya rumput laut adalah $50 \mathrm{~cm}$. Perbedaan metode budidaya menyebabkan rumput laut berada pada kedalaman yang berbeda. Semakin dalam perairan maka intensitas cahaya semakin berkurang sehingga proses fotosintesis tidak optimal. Menurut Sujatmiko dan Wisman (2003) rumput laut yang berada di permukaan relatif lebih banyak mendapatkan cahaya matahari dibandingkan rumput laut yang berada di bagian yang lebih dalam. Widyartini dan Insan (2004) menambahkan intensitas cahayayang diterima semakin kecil, maka proses fotosintesis terhambat dan pertumbuhan tidak optimal.

\section{KESIMPULAN}

Kualitas agar rendemen rumput laut Gracilaria gigas tertinggi didapatkan pada perlakuan A2 (42.49\%). Sedangkan kualitas agar rendemen rumput laut terendah didapatkan pada perlakuan C2 $(26.66 \%)$. Pertumbuhan rumput laut Gracilaria gigas terbaik didapatkan pada perlakuan dengan kedalaman tanam $40 \mathrm{~cm}$ (Perlakuan B). Pertumbuhan bobot mutlak tertinggi didapatkan dengan berat 0,64 $\mathrm{g}$ dan laju pertumbuhan harian tertinggi didapatkan dengan berat $0,14 \%$ /hari.

\section{UCAPAN TERIMAKASIH}

Penulis menyampaikan terimakasih kepada Dosen Fakultas Pertanian, Program Studi Akuakultur Universitas Muhammadiyah Gresik yang telah memberikan ilmu di bidang Perikanan yang sangat membantu dalam proses penyelesaian studi di UMG.

\section{DAFTAR PUSTAKA}

Anam, M.S. 2007. Petunjuk Budidaya Polikultur Rumput Laut, Bandeng dan Udang di Tambak. Kantor Ketahanan Pangan dan Penyuluhan Pertanian Kabupaten Pasuruan. Pasuruan.

Anggadiredja, J.T. Purwoto, I.S. dan Zatnika, A. 2009. Rumput Laut Penebar Swadaya. Jakarta.

Aslan, L.M. 2006. Budidaya Rumput Laut. Kanisius .Yogyakarta. 
Association of Official Analytical Chemist (AOAC). 2005. Official Methods of Analysis of the Association of Official Analytical Chemist. Virginia USA: Association of Official Analytical Chemist.

Kadi, A. Atmadja, W.S. 1988. Rumput Laut Jenis Algae. Reproduksi, Produksi, Budidaya dan Pasca Panen. Proyek Studi Potensi Sumberdaya Alam Indonesia. Jakarta: Pusat penelitian dan Pengembangan Oseanologi. Lembaga Ilmu Pengetahuan Indonesia. Jakarta.

Kompas. 2008. Rumput Laut. Hanya 15 Persen Diolah di Indonesia. Tanggal 15September 2008.

McHugh, D.J. 2003.A guide to seaweed industry.FAO Fisheries Technical Paper No. 441.FAO.Rome, $105 \mathrm{pp}$.

Mubarak,H. Ilyas, S. Ismail, W. Wahyuni, I.S. Hartati, S.H. Pratiwi, E. Jangkaru, Z dan Arifuddin, R. 1990. Petunjuk teknis budidaya rumput laut. Badan Litbang Pertanian,Puslitbang Perikanan. IDRC, Infish. 93 hal.

Sujatmiko, W dan Angkasa,W.I. 2003. Teknik Budidaya Rumput Laut denganMetode Tali Panjang.http ://www.iptek.net.id/ttg/artlk/artikel 18.html.

Satari, R. 2001. Karakterisasi Polisakarida Agar dari Gracilaria sp. dan Gelidium sp.Kumpulan makalah seminar maritim indonesia, perikanan : 227-245.

Widyartini, D.S. danInsan, A.I. 2004.Produksi Rumput Laut Gracilaria gigas danGracilaria verrucosa Dengan Sistem Budidaya Yang Berbeda di Perairan Tambak Kebumen.Laporan Penelitian Fakultas biologi Unsoed.Purwokerto.

Zatnika, A. 1997.Profil industri rumput laut Indonesia. Tim Rumput Laut BPPT. BPPT. Jakarta.

Zatnika, A. 2009. Pedoman Teknis Budidya Rumput Laut. Badan Pengkajian dan Penerapan Teknologi. Jakarta.

Zatnika, A. dan Istini, S. 2009. Optimasi Perlakuan Alkali Dalam Upaya Peningkatan Kualitas Agar Dari Rumput Laut (Gracilaria spp.). Badan Pengkajian dan Penerapan Teknologi. Jakarta. 